\title{
Inoceramid bivalve and dinoflagellate cyst integrated biostratigraphy of the topmost Campanian-Maastrichtian in a part of the Western Fore-Balkan Mountains, northwest Bulgaria
}

\author{
Polina Pavlishina ${ }^{1}$, Docho Dochev1 ${ }^{1}$ Lubomir Metodiev², Eliza Vladimirova ${ }^{1}$ \\ ${ }^{1}$ Department of Geology, Palaeontology and Fossil Fuels, Sofia University “St Kliment Ohridski”, 15 Tsar Osvoboditel Blvd, \\ 1504 Sofia, Bulgaria; emails: polina@gea.uni-sofia.bg; dochev@gea.uni-sofia.bg; e.a.vladimirova@abv.bg \\ ${ }^{2}$ Geological Institute, Bulgarian Academy of Sciences, Acad. G. Bonchev Str., Block 24, 1113 Sofia, Bulgaria; \\ e-mail: lubo@geology.bas.bg
}

(Accepted in revised form: December, 2020)

\begin{abstract}
We present the inoceramid and dinoflagellate cyst record from the topmost CampanianMaastrichtian strata of three key sections of the Western Fore-Balkan Mountains, northwest Bulgaria. The following inoceramid zones were recognized: “Inoceramus” redbirdensis Zone, Endocostea typica Zone, Trochoceramus radiosus Zone and "Inoceramus" ianjonaensis Zone. The Campanian/Maastrichtian boundary was tentatively drawn slightly below the first occurrence of Endocostea typica. The uppermost inoceramid assemblage was confined to the lower part of the upper Maastrichtian. Dinoflagellate cyst ranges, as well as the first and the last occurrence events of dinocysts, provided valuable markers for the stratigraphic subdivision of the Maastrichtian. The first occurrence of Microdinium carpentierae was documented in proximity to the Campanian/Maastrichtian boundary. The Cerodinium diebelii Zone was recognized with a stratigraphical range from the lower Maastrichtian to the lower upper Maastrichtian. The last occurrence of Alterbidinium acutulum was recorded in the lower Maastrichtian and used as aid for tracing the lower/upper Maastrichtian substage boundary. The marked domination of delicate chorate dinocysts in all sections and the encountered low P/G ratio values are indicative of stable low-energy depositional environment and oligotrophic conditions, with normal marine productivity and nutrient availability in the basin during the Maastrichtian.
\end{abstract}

Pavlishina, P, Dochev, D., Metodiev, L., Vladimirova, E. 2020. Inoceramid bivalve and dinoflagellate cyst integrated biostratigraphy of the topmost Campanian-Maastrichtian in a part of the Western Fore-Balkan Mountains, northwest Bulgaria. Geologica Balcanica 49 (3), 39-63.

Keywords: inoceramids, dinoflagellate cysts, uppermost Campanian-Maastrichtian, Western ForeBalkan Mountains, northwest Bulgaria.

\section{INTRODUCTION}

Inoceramid bivalves are a valuable fossil group for the dating and subdivision of Upper Cretaceous rocks as they have both high evolutionary rates and wide geographical distribution (e.g., Dhondt, 1993; Kauffman et al., 1993; Crampton, 1996; Harries and Crampton, 1998; Odin, 2001; Gale et al., 2008). In addition, the progressive biostratigraphical refinement of the inoceramid zonation now allows very fine discrimination and correlation, particularly for the Campanian-Maastrichtian interval (see Walaszczyk et al., 2002a, b, 2009).
Dinoflagellate cysts are a fossil group with rising potential for stratigraphic age assessment of Upper Cretaceous strata, especially of Campanian and Maastrichtian sediments. During the last decades, a large number of sections, both from the Tethyan and Boreal realms, have been studied in order to establish a sound palynostratigraphic framework for the Campanian-Maastrichtian interval (e.g., Kirsch, 1991; Schioler and Wilson, 1993, 2001; Roncaglia, 2002; Skupien and Mohamed, 2008; Radmacher et al., 2014). These studies have created a detailed and comprehensive overall dataset, in which the dinoflagellate cyst ranges, as well as first and last occur- 
rence events (FO and LO), provide valuable markers for stratigraphic subdivision of both the Campanian and the Maastrichtian and even for drawing the Campanian/Maastrichtian boundary (see Odin et al., 2001; Radmacher et al., 2014).

In Bulgaria, the stratigraphic potential of both inoceramid bivalves and dinoflagellate cysts from the Upper Cretaceous is still underused. Traditionally used age-defining fossils, such as ammonites, cannot provide high resolution due to their scattered occurrence (Jolkičev, 1989). Recent attempts have enabled us to record a few sections anew and collect good fossil material (Dochev et al., 2018; Dochev and Metodiev, 2015, 2020), as well as to correlate them with type localities outside Bulgaria. This paper presents correlated di- nocyst and inoceramid biostratigraphic data from the topmost Campanian-Maastrichtian strata of NW Bulgaria. It places particular emphasis on this interval since both inoceramid bivalves and dinoflagellate cysts yielded stratigraphically significant taxa and allowed valuable bioevents to be recognized in Bulgaria.

\section{STRATIGRAPHIC BACKGROUND}

The Western Fore-Balkan Mts region takes part of the western Central Balkan-Fore-Balkan tectonic zone that forms the northern marginal segment of the Balkan orogenic system in Bulgaria (Ivanov, 1998, 2017) (Fig. 1a). Along the Iskar River Valley, north

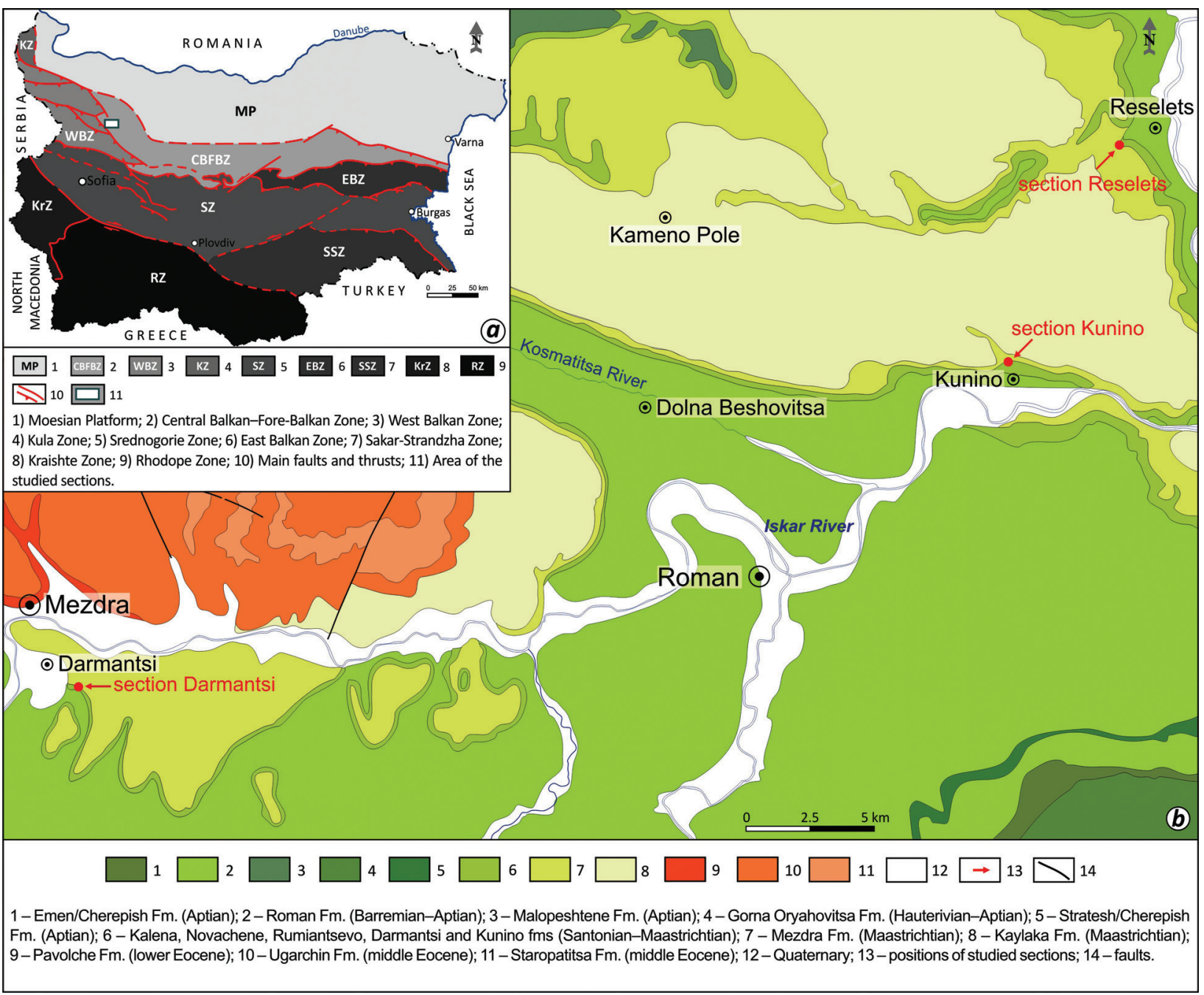

Fig. 1. Location maps of the sections that yielded the fossils for this study: $a$ ) tectonic sketch map of Bulgaria, showing the area of this study (after Ivanov, 1998, 2017); b) geological sketch map of the Western Fore-Balkan Mts in the area around the town of Mezdra (after Tzankov et al., 1994, 1995; simplified). 
of the town of Mezdra, it is a foothill area, which is composed of shallow- to moderately deep-water epicontinental carbonate-siliciclastic Cretaceous-Eocene deposits (Fig. 1b). The Upper Cretaceous strata of this area correspond to moderately expanded Campanian-Maastrichtian carbonates, into which four formal lithostratigraphic units have been recognized (Jolkičev, 1986): the Darmantsi, Kunino, Mezdra and Kaylaka formations. The Darmantsi Formation (upper Campanian-lower Maastrichtian) comprises green glauconitic limestones, sandstones and grey, slightly glauconitic, clayey limestones, containing rare ammonites, belemnites and inoceramid bivalves. The Kunino Formation (lower Maastrichtian) is composed of grey clayey limestones rarely interbedded with marls. Limestones contain abundant and diverse inoceramid fauna and relatively common ammonites. The Mezdra Formation (Campanian-lower Paleocene) consists of grey to light grey micritic limestones with flint concretions, often containing belemnites, echinoids and scattered ammonites (see also Dabovski et al., 2009). The Kaylaka Formation is not taken into considerations herein as it is beyond the scope of the present study.

The outcrops of the Upper Cretaceous strata near the villages of Reselets, Kunino and Darmantsi (Pleven and Vratsa districts) have long attracted attention with their good exposures and fossils, but served as a basis for detailed stratigraphic and paleontological studies in the area in late 1970s. Jolkičev (1982) described in the vicinity of Reselets Village two sections: along the valley of the Beliloto River and near Reselets railway station, the latter located on the western slopes of the natural landmarks Kokala and Kuklite. Based on poor inoceramid material, rare ammonites, belemnites and foraminifers, both sections were dated as Santonian-Maastrichtian. Jolkičev (1982) also made a detailed description of the section near Kunino Village (upper Campanian-lower Maastrichtian) and later designated the stratotype for the Kunino Formation (Jolkičev, 1986). In addition, Jolkičev (1986) gave a detailed account of the section near Darmantsi Village and designated the stratotype for the Darmantsi Formation (lower Maastrichtian).

Following the earlier works of Jolkičev, we studied anew the Reselets, Kunino and Darmantsi sections. Regrettably, the successions near Reselets Village are currently not available for revisions. Therefore, we (LM and DD) chose a new outcrop, which is located $1 \mathrm{~km} \mathrm{SW}$ of Reselets, near the former tourist hut. It corresponds to a 15-m thick sedimentary succession including the uppermost part of the Darmantsi Formation, the entire vertical extent of the Kunino Formation, as well as the base of the
Mezdra Formation (see Fig. 2). The Reselets section yielded seven inoceramid-bearing horizons, with a marked abundance of specimens from the Kunino Formation and especially from the Mezdra Formation.

The Kunino section is still well exposed and comprises a 16.5-m thick succession containing the upper part of the Darmantsi Formation, the type section for the Kunino Formation and the lower part of the Mezdra Formation (see Fig. 3). It is located at the northern end of the village after which it was named. The rocks of the Kunino Formation yielded abundant and well-preserved inoceramid bivalves, dinocyst assemblages and scattered ammonite fauna from eight fossiliferous levels. Dinocyst and inoceramid data of a lesser amount were also obtained from the Darmantsi and Mezdra formations.

The Darmantsi section is a composite section in the river valley south of the village. It is $14 \mathrm{~m}$ thick and includes the type section for the Darmantsi Formation, the Kunino Formation and the base of the Mezdra Formation (see Fig. 4). The rocks of the Darmantsi Formation yielded poorly preserved inoceramids, dinocyst assemblages and very rare fragmentary ammonites. Rare inoceramid bivalves and ammonites were also collected from the middle part of the Kunino Formation. From the latter, we obtained dinocyst data, as well as from the Mezdra Formation.

\section{MATERIAL AND METHODS}

A total of 300 inoceramid bivalves were studied. The inoceramid material was collected mostly from clayey limestones and consists of internal molds of single valves. Shell fragments are attached to some specimens. In addition, 25 palynological samples were collected from the studied sections. Fifteen of them were positive for dinoflagellate cysts. The samples were preferentially taken from soft marly beds, as preliminary investigation determined more favorable abundances in them. The samples were processed according to standard palynological techniques. About $50 \mathrm{~g}$ of sediment was processed with $\mathrm{HCl}$ and $\mathrm{HF}$ treatment, heavy liquid separation and $\mathrm{KOH}$ treatment. The residues were finally sieved through 6-8 $\mu$ m nylon meshes. Strew mounts were made in glycerin jelly. From each of the samples, two palynological strew mounts were prepared and analyzed for their palynological content. The inoceramid collection and palynological slides used for this study are housed at the Museum of Palaeontology and Historical Geology at Sofia University "St Kliment Ohridski”, Bulgaria. 


\section{BIOSTRATIGRAPHIC RESULTS}

As can be seen from the stratigraphic logs (Figs 2-4), both the inoceramid and dinocyst assemblages are satisfactorily traceable in superposition in the sections. The inoceramid material mostly comprises small- to medium-sized specimens, of which Cataceramus is the dominant genus, and Endocostea, Platyceramus, Trochoceramus and "Inoceramus" are less common. Dinocysts assemblages are rich and relatively well preserved. They contain key species, such as Odontochitina operculata, Microdinium carpentierae, Cerodinium diebelii, Cannosphaeropsis utinensis, Alterbidinium acutulum, Isabelidinium cooksoniae, Sulculospaheridium longifurcatum, Triblastula utinensis, Hystrichospaheridium tubiferum, $H$. salpingophorum and Tanyosphaeridium xanthiopyxides. The biostratigraphic subdivision applied herein (Fig. 5) is based on published reference inoceramid and dinocyst successions from NW Europe, the U.S. Western Interior Basin and South Africa (Kirsch, 1991; Roncaglia and Corradini, 1997; Schioler and Wilson, 1993, 2001; Roncaglia, 2002; Walaszczyk et al., 2001, 2002a, b, 2009; Walaszczyk, 2004). The best-preserved specimens of the most representative taxa are illustrated in Figs 6-13.

\section{Reselets section}

The middle part of the Darmantsi Formation (bed 3) yielded the oldest inoceramid record of the Reselets section; "Inoceramus" cf. wyomingensis Walaszczyk, Cobban and Harries (see Fig. 2). Dochev et al. (2018) reported Pseudokossmaticeras brandti Redtenbacher, which is exactly from this bed. Both species are characteristic for the uppermost Campanian, and the presence of "I." cf. wyomingensis was taken as an indication for the "Inoceramus" redbirdensis Zone (see Walaszczyk et al., 2001). The co-occurrence of the dinocyst taxa Achomosphaera ramulifera, Spiniferites ramosus ramosus, S. membranaceus, and especially of Odontochitina operculata, is also indicative of the latest Campanian age of this level. Odontochitina operculata was also found slightly higher in the section (bed 5), but not in subsequently higher levels. The latter record is akin to those reported in proximity to the Campanian/Maastrichtian boundary at Tercis (France) and Zumaia (Northern Spain) (Schioler and Wilson, 2001; Radmacher et al., 2014), as well as elsewhere (e.g., northern Apennines - Roncaglia, 2002; western Carpathians - Skupien and Mohamed, 2008; see also Williams et al., 2004).

The inoceramids from the next higher bed (4) of Reselets differ significantly as being more in number and composing a new assemblage of Endocostea typica Whitfield, Cataceramus subcircularis (Meek) and C. palliseri (Douglas). Dinocysts of this bed yielded Microdinium carpentierae and Tanyosphaeridium xanthiopyxides. Of these, the occurrence of E. typica and the presence of M. carpentierae confine the fossil association to the lowermost Maastrichtian (see Walaszczyk et al., 2001; Schioler and Wilson, 2001).

Up-section, in the lower part of the Kunino Formation (bed 5), a dinocyst assemblage comprising Sulculospaheridium longifurcatum, S. ramosus ramosus, S. membranaceus, Hystrichospaheridium tubiferum, O. operculata and Peridinium cingulatum was recorded. It was not supported by inoceramid specimens, but the inoceramids from bed 7 , slightly above, compose a typically lower Maastrichtian assemblage, consisting of E. typica, Cataceramus palliseri, C. subcircularis and C. barabini (Morton). Bed 7 also yielded dinocyst taxa that were recorded in the lower levels (see Fig. 2).

After an interval devoid of dinocysts, in which rare specimens of $C$. palliseri (bed 10), C. oviformis and $E$. typica (bed 13 ) were obtained, bed 17 yielded an abundant inoceramid assemblage of E. typica, $C$. subcircularis, C. barabini, C. oviformis and Cataceramus glendivensis Walaszczyk, Cobban and Harries. The presence of $C$. glendivensis indicates the upper part of the lower Maastrichtian E. typica Zone (Walaszczyk et al., 2001, 2009).

At the lithological transition between the Kunino and Mezdra formations (beds 18-21), no fossils were found, but the very base of the Mezdra Formation (beds 22, 23) contributed with two fossiliferous levels. Well-preserved and abundant inoceramid specimens of $C$. subcircularis, C. palliseri, C. barabini and C. glendivensis occur in bed 22, whereas, in the overlying bed 23, common specimens of $C$. barabini, C. oviformis and C. glendivensis were found (Fig. 2). From bed 23, well-preserved but problematic inoceramids, defined as Cataceramus spp., were also obtained. These specimens are very close to those recorded from the lower part of the Darmantsi section (see bed 3 below) and correspond to very prosocline inoceramids, with beak projecting above a long and straight hinge line, and variable ornamentation (low, regularly to irregularly spaced rugae, with rugae interspaces increasing ventralward). They may belong to the morphogroup of Cataceramus ghadamesensis (Tröger, in Tröger and Röhlich), but more material is needed to make a taxonomic decision. The dinocyst assemblage consists of Achomosphaera sagena, A. ramulifera, S. longifurcatum, S. ramosus ramosus and Hystrichospaheridium tubiferum. 


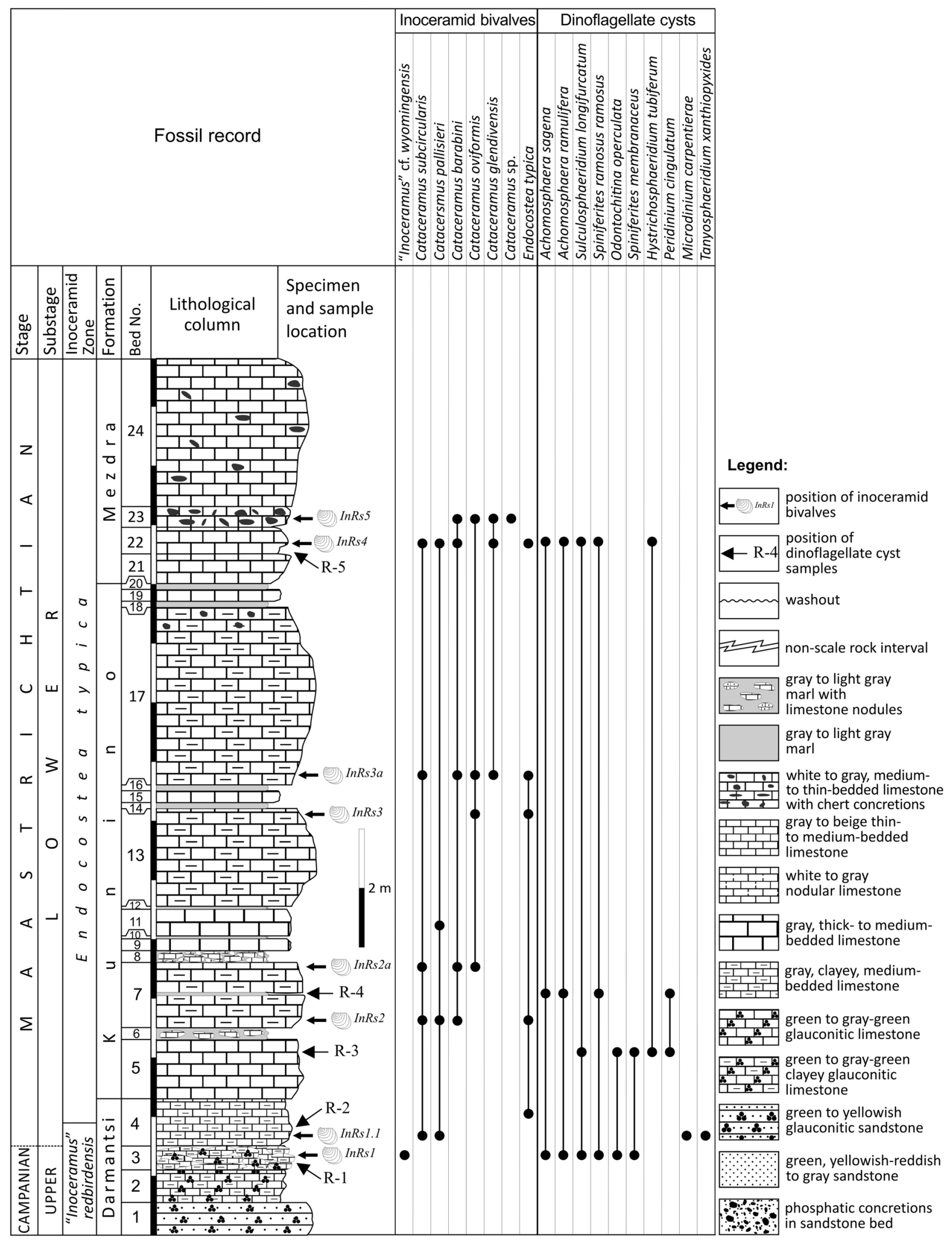

Fig. 2. Stratigraphic log of the Reselets section, showing the lithology, inoceramid zonation and the ranges of inoceramids and dinoflagellate cysts. 


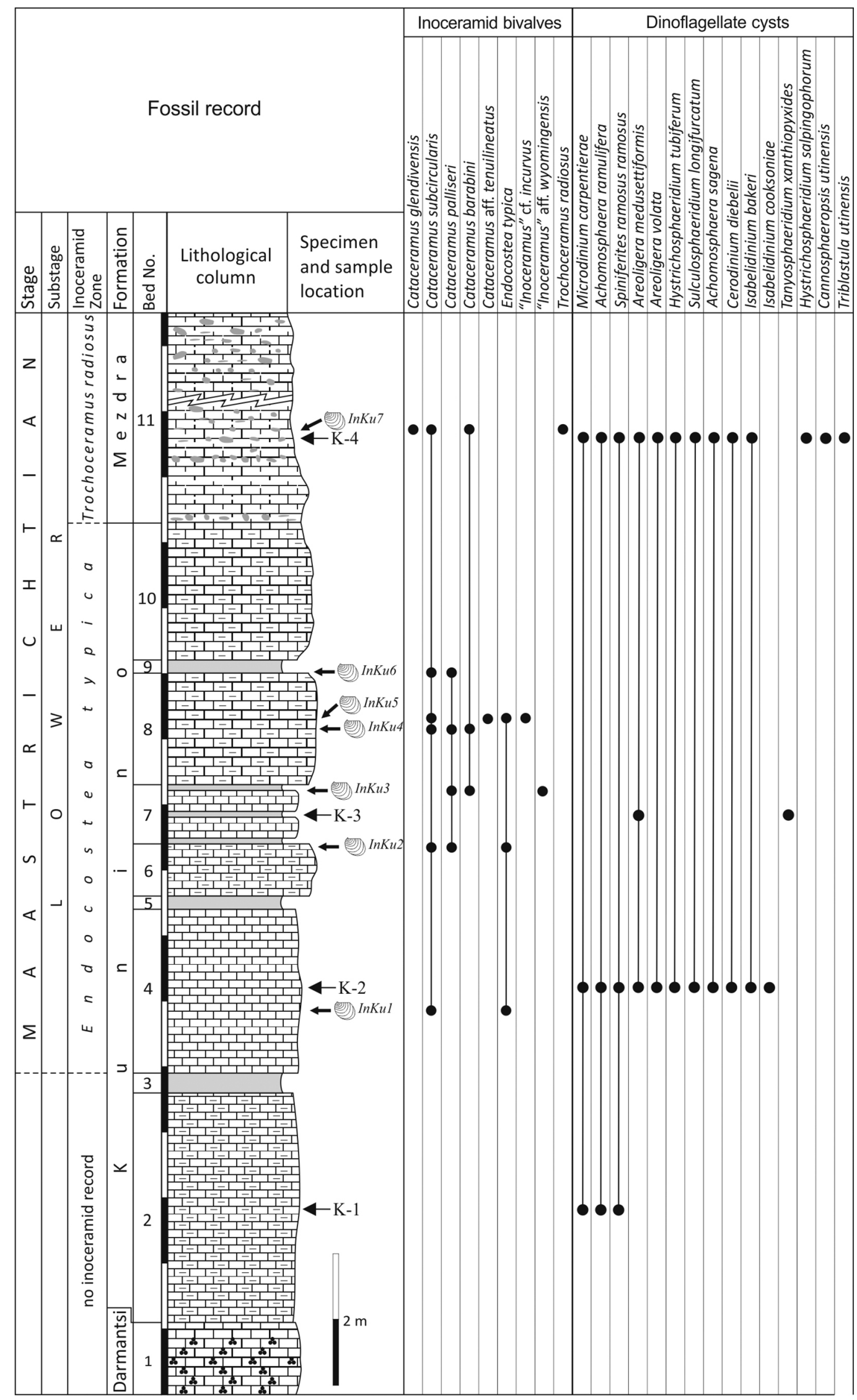

Fig. 3. Stratigraphic log of the Kunino section, comprising the inoceramid zonation and vertical distribution of the recorded inoceramids and dinoflagellate cysts. For lithology, see the legend in Fig. 2. 


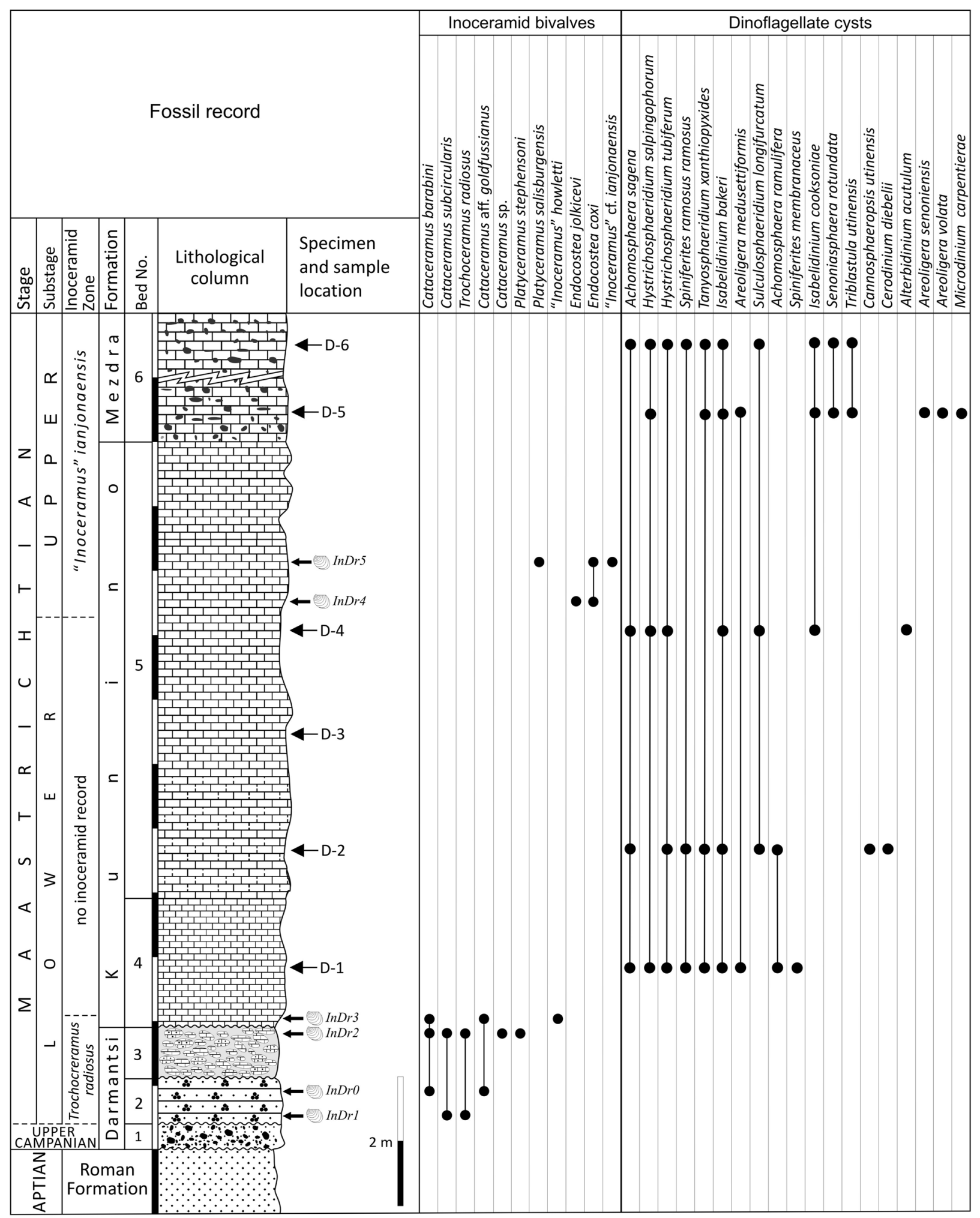

Fig. 4. Stratigraphic log of the Darmantsi section, comprising the inoceramid zonation and the ranges of inoceramids and dinoflagellate cysts. For lithology, see the legend in Fig. 2. 


\begin{tabular}{|c|c|c|c|c|c|c|c|c|}
\hline \multicolumn{2}{|c|}{ Tercis } & \multirow[b]{2}{*}{$\begin{array}{l}\text { U.S. Western Interior } \\
\text { (Walaszczyk et al., 2001) }\end{array}$} & \multirow[b]{2}{*}{$\begin{array}{l}\text { Tercis section, France } \\
\text { (Walaszczyk et al., 2002) }\end{array}$} & \multirow[b]{2}{*}{$\begin{array}{c}\text { Western Fore-Balkan } \\
\text { (this paper) }\end{array}$} & \multirow[b]{2}{*}{$\begin{array}{c}\text { Zululand and Natal } \\
\text { (South Africa) } \\
\text { (Walaszczyk et al., 2009) } \\
\text { (pars.) }\end{array}$} & \multicolumn{2}{|c|}{ Boreal } & \multirow[b]{2}{*}{$\begin{array}{c}\text { Vistula section } \\
\text { (Poland) } \\
\text { (Walaszczyk, 2004) } \\
\text { (pars.) }\end{array}$} \\
\hline 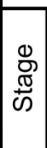 & $\mid$\begin{tabular}{c|}
0 \\
0 \\
$\frac{\pi}{0}$ \\
0 \\
0 \\
0 \\
$\omega$
\end{tabular} & & & & & 焉 & 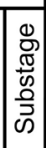 & \\
\hline \multirow{4}{*}{ 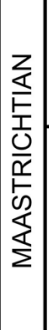 } & \multirow{4}{*}{ 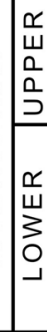 } & & & \multirow{3}{*}{$\begin{array}{c}\text { "Inoceramus" } \\
\text { ianjonaensis } \\
-------- \\
\begin{array}{c}\text { Trochoceramus } \\
\text { radiosus }\end{array}\end{array}$} & \multirow{7}{*}{$\begin{array}{c}\text { "Inoceramus" } \\
\text { ianjonaensis } \\
------- \\
\text { Trochoceramus } \\
\text { radiosus }\end{array}$} & \multirow{7}{*}{ 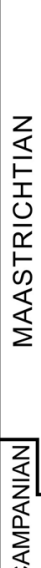 } & \multirow{6}{*}{ 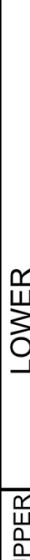 } & \\
\hline & & Inoceramus balchi & & & & & & \\
\hline & & Trochoceramus radiosus & Trochoceramus radiosus & & & & & \\
\hline & & $\begin{array}{c}\text { Inoceramus incurvus } \\
\text { Endocostea typica }\end{array}$ & Endocostea typica & Endocostea typica & & & & $\begin{array}{c}\text { Endocostea } \\
\text { typica }\end{array}$ \\
\hline \multirow{3}{*}{$\mid \begin{array}{l}z \\
z \\
z \\
z \\
\alpha \\
z \\
\sum \\
⿱ \\
0\end{array}$} & \multirow{3}{*}{ 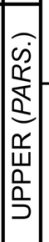 } & $\begin{array}{l}\text { Inoceramus } \\
\text { redbirdensis }\end{array}$ & Inoceramus redbirdensis & \multirow[t]{3}{*}{$\begin{array}{l}\text { Inoceramus } \\
\text { redbirdensis }\end{array}$} & & & & $\begin{array}{l}\text { Inoceramus } \\
\text { redbirdensis }\end{array}$ \\
\hline & & \multirow{2}{*}{$\begin{array}{l}\text { Inoceramus } \\
\text { oblongus }\end{array}$} & Trochoceramus & & & & & $\begin{array}{l}\text { Trochoceramus } \\
\text { costaecus }\end{array}$ \\
\hline & & & $\begin{array}{l}\text { Inoceramus } \\
\text { oblongus }\end{array}$ & & & & 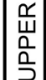 & $\begin{array}{l}\text { Inoceramus } \\
\text { inkermanensis }\end{array}$ \\
\hline
\end{tabular}

Fig. 5. Correlation of the inoceramid zonation for the uppermost Campanian-Maastrichtian interval applied herein, with the inoceramid zonation in the U.S. Western Interior, the Tercis section (France), Zululand and Natal (South Africa) and the Vistula section (Central Poland).

\section{Kunino section}

The lowermost beds of the Kunino section, which correspond to the Darmantsi Formation and the very base of the Kunino Formation (beds 1-3), are completely barren of inoceramid bivalves (Fig. 3). These strata yielded a few dinocyst taxa: Microdinium carpentierae, Achomosphaera ramulifera and Spiniferites ramosus ramosus, which denote possibly lowermost Maastrichtian. The oldest inoceramids were recorded in the middle part of bed
4 and confirm the age from below. This level is the first of six successive inoceramid faunal levels that can be distinguished at Kunino. The inoceramids are represented by small-sized Endocostea typica and Cataceramus subcircularis, and therefore were taken to mark the E. typica Zone. Slightly above this level, a dinocyst assemblage, consisting of the species found below and also $S$. ramosus ramosus, Areoligera medusettiformis, A. volata, Hystrichospaheridium tubiferum, Sulculospaheridium longifurcatum, Achomosphaera sa-

Fig. 6. Topmost Campanian-lower Maastrichtian inoceramid bivalves from the Western Fore-Balkan Mts region: $a$ ) "Inoceramus" cf. wyomingensis Walaszczyk, Cobban and Harries (Inv.-Nr U.S., $\mathrm{K}_{2}$ 1747), Reselets section (upper part of bed 3), "Inoceramus” redbirdensis Zone; $b-h$ ) Endocostea typica Whitfield: $b$ - Inv.-Nr U.S., $K_{2} 1755$, Reselets section (upper part of bed 13), lower part of the E. typica Zone; $c$ - Inv.-Nr U.S., $\mathrm{K}_{2}$ 1754, Reselets section (lower part of bed 7), lower part of the E. typica Zone; $d$ - Inv.-Nr U.S., $\mathrm{K}_{2}$ 1760, Kunino section (middle part of bed 4), lower part of the E. typica Zone; $e$ - Inv.-Nr U.S., $\mathrm{K}_{2}$ 1756, Reselets section (lower part of bed 17), upper part of the E. typica Zone; $f$ - Inv.-Nr U.S., $K_{2} 1765$, Kunino section (uppermost part of bed 6), lower part of the E. typica Zone; $g$ - Inv.-Nr U.S., $\mathrm{K}_{2}$ 1748, Reselets section (bed 4), base of the E. typica Zone; $h$ - Inv.-Nr U.S., K 1793, Kunino section (middle part of bed 8), upper part of the E. typica Zone; i) Cataceramus subcircularis (Meek) (Inv.-Nr U.S., $\mathrm{K}_{2}$ 1763a), Reselets section (bed 22), upper part of the E. typica Zone. j) Cataceramus oviformis Walaszczyk, Cobban and Harries (Inv.-Nr U.S., $\mathrm{K}_{2}$ 1763), Reselets section (base of bed 17), lower part of the E. typica Zone; $k$ ) Cataceramus subcircularis (Meek) (Inv.-Nr U.S., $\mathrm{K}_{2}$ 1791), Kunino section (lower part of bed 11), upper part of the E. typica Zone. Figured specimens were covered with ammonium chloride before being photographed. All figures are in natural size. 


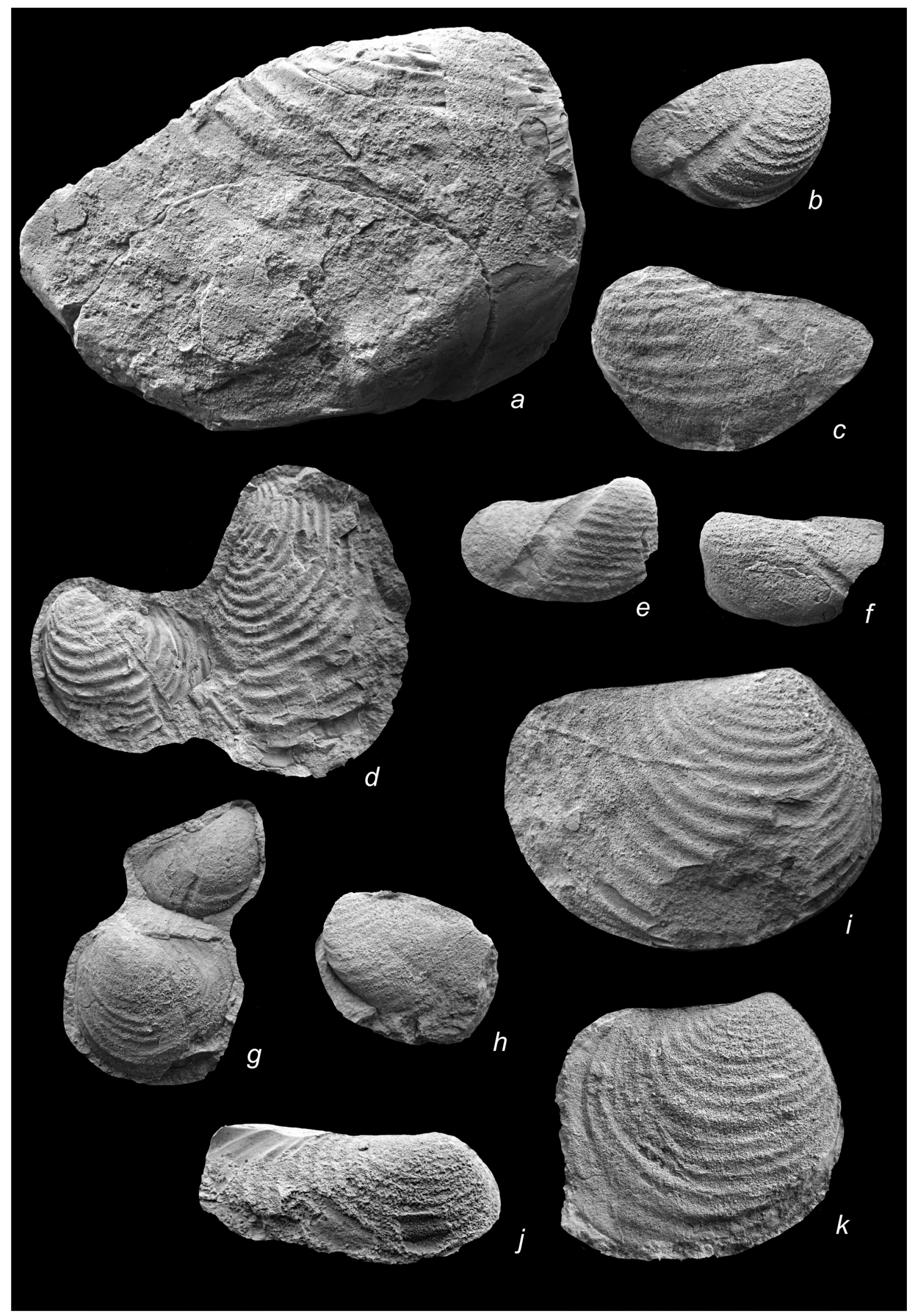







Fig. 7. Lower Maastrichtian inoceramid bivalves from the Western Fore-Balkan Mts region: $a, b, e-g$ ) Cataceramus subcircularis (Meek): $a$ - Inv.-Nr U.S., $\mathrm{K}_{2}$ 1757, Reselets section (bed 22), upper part of the E. typica Zone; $b$ - Inv.-Nr U.S., K 2 1774, Reselets section (base of bed 17), lower part of the E. typica Zone; $e$ - Inv.-Nr U.S., $\mathrm{K}_{2}$ 1766, Kunino section (upper part of bed 8), upper part of the E. typica Zone; $f$ - Inv.-Nr U.S., $\mathrm{K}_{2}$ 1792, Kunino section (upper part of bed 6), lower part of the E. typica Zone; $g$ - Inv.-Nr U.S., $K_{2}$ 1790, Kunino section (base of bed 9), upper part of the E. typica Zone; c, d) Cataceramus palliseri (Douglas): $c$ - Inv.-Nr U.S., $\mathrm{K}_{2}$ 1752, Reselets section (base of bed 7), lower part of the E. typica Zone; $d$ - U.S., $\mathrm{K}_{2}$ 1751, Reselets section (bed 11), lower part of the E. typica Zone; h) Cataceramus aff. tenuilineatus sensu Whitfield, Inv.-Nr U.S., $\mathrm{K}_{2}$ 1767, Kunino section (upper part of bed 8), upper part of the E. typica Zone; i) Cataceramus barabini (Morton), Inv.-Nr U.S., $\mathrm{K}_{2}$ 1778, Darmantsi section (lower part of bed 4), Trochoceramus radiosus Zone. Figured specimens were covered with ammonium chloride before being photographed. All figures are in natural size.

gena, Cerodinium diebelii, Isabelidinium bakeri and I. cooksoniae, were recorded.

Up-section, from the uppermost parts of beds 6-7, E. typica, C. subcircularis and C. palliseri were collected. Bed 7 sees the incoming of Cataceramus barabini in succession. Thus, the recognition of E. typica Zone is firm. A specimen determined as "Inoceramus" aff. wyomingensis was also found in the uppermost part of the bed. It has dissimilar stratigraphic position from "I." wyomingensis and is left in open nomenclature as having different rugae direction and sculpture in the juvenile part from the typical representatives of this species. Bed 7 also yielded Areoligera medusettiformis and Tanyosphaeridium xanthiopyxides.

The inoceramids from bed 8 represent the most abundant and diverse assemblage for the entire section. They occur at three successive levels, in which E. typica, C. subcircularis, C. palliseri and C. barabini are the most common, but single specimens of Cataceramus aff. tenuilineatus Hall and Meek and "Inoceramus" cf. incurvus are also present. The latter species is indicative of the upper part of the $E$. typica Zone.

The uppermost inoceramid record from the Kunino section is confined to the base of the Mezdra Formation (bed 11). The inoceramid fauna is abundant and mostly consists of medium-sized bivalves of Cataceramus, namely C. glendivensis and $C$. subcircularis, but Trochoceramus radiosus (Quaas) also occurs (see Fig. 3). Of these taxa, the latter one is a guide-fossil for the upper lower Maastrichtian T. radiosus Zone (Walaszczyk et al., 2001, 2009, 2010). Abundant dinocyst assemblage was recorded in bed 11, in which, with the exception of $T$. xanthio- pyxides, all taxa identified at the lower levels of the succession occur (see Fig. 3).

From palynostratigraphic point of view, the encountered dinocyst association at Kunino indicates the Cerodinium diebelii Interval Zone (Kirsch, 1991; Roncaglia and Corradini, 1997). Characteristic species of the zone are Cerodinium diebelii, Microdinium carpentierae, Cannosphaeropsis utinensis, Triblastula utinensis, Isabelidinium cooksoniae, I. bakeri, Tanyosphaeridium xanthiopyxides and Areoligera volata. The zone is also characterized by the conspicuous acme of $C$. utinensis in its upper part (bed 11). The latter taxon occurs in the lower Maastrichtian of southern Germany and its LO was reported around the lower/upper Maastrichtian boundary (Williams et al., 2004). According to the original definition of Kirsch (1991), the LO of C. utinensis is within the Alterbidinium varium Subzone, which spans the lower Maastrichtian interval of the Cerodinium diebelii Zone. The concurrent presence of $C$. utinensis and $C$. diebelii in the upper part of the Kunino section evidences that the strata are not younger than the early Maastrichtian, based on dinocyst data.

\section{Darmantsi section}

We did not find any inoceramids at the very base of the Darmantsi Formation (bed 1), but Jolkičev (1986) dated this level as late Campanian, based on belemnite taxa and scattered ammonites. In the following two beds (2 and 3) of the Darmantsi Formation, we found an assemblage of medium-sized C. subcircularis, C. barabini and Cataceramus aff. goldfussianus (d'Orbigny), accompanied by me- 





Fig. 8. Lower Maastrichtian inoceramid bivalves from the Western Fore-Balkan Mts region: a) Cataceramus subcircularis Meek, Inv.-Nr U.S., $\mathrm{K}_{2}$ 1758, Reselets section (bed 23), upper part of the E. typica Zone; b) Cataceramus sp., Inv.-Nr U.S., K 2 1789, Darmantsi section (upper part of bed 3), T. radiosus Zone; c) Cataceramus sp., Inv.-Nr U.S., $\mathrm{K}_{2}$ 1759, Reselets section (bed 23), upper part of the E. typica Zone; d) Cataceramus glendivensis Walaszczyk, Cobban and Harries, Inv.-Nr U.S., K 2 1771, Kunino section (bed 11), Trochoceramus radiosus Zone; e, g) Cataceramus cf. subcircularis Meek, Inv.-Nr U.S., $\mathrm{K}_{2}$ 1773, Reselets section (bed 22), upper part of the E. typica Zone; f) Cataceramus subcircularis Meek, Inv.-Nr U.S., $\mathrm{K}_{2}$ 1781, Darmantsi section (base of bed 4), Trochoceramus radiosus Zone; h) Cataceramus glendivensis Walaszczyk, Cobban and Harries, Inv.-Nr U.S., $\mathrm{K}_{2}$ 1749, Reselets section (bed 17), upper part of the E. typica Zone. Figured specimens were covered with ammonium chloride before being photographed. All figures are in natural size.

dium- to large-sized Trochoceramus radiosus and Platyceramus stephensoni (Walaszczyk, Cobban and Harries) (see Fig. 4). Inoceramids defined as Cataceramus sp., from the same morphological type as the material from the Reselets section (bed 23, see above), were documented in the uppermost part of bed 3 . This assemblage indicates the $T$. radiosus Zone, and therefore reveals a non-sequence within the Darmantsi section that corresponds to the lowermost Maastrichtian. Slightly above it, at the very base of the Kunino Formation (bed 4), we found a Cataceramus-dominated assemblage, consisting of large specimens. This assemblage is composed of C. aff. goldfussianus and C. barabini, but "Inoceramus" howletti Walaszczyk, Kennedy and Klinger was also recorded. According to Walaszczyk et al. (2009), "I." howletti is a characteristic element of the $T$. radiosus Zone.

Up-section, the Kunino Formation is almost devoid of inoceramids. No inoceramids were found in the Mezdra Formation either. This segment of the succession mainly contributed with characteristic lower Maastrichtian dinocysts recorded in five levels: Cerodinium diebelii, Cannosphaeropsis utinensis, Isabelidinium bakeri, I. cooksoniae, Areoligera medusettiformis, A. senoniensis, A. volata, Alterbidinium acutulum, Tanyosphaeridium xanthiopyxides, Triblastula utinensis, Microdinium carpentierae and Senoniasphaera reticulata. These taxa are indicative of the Cerodinium diebelii Interval Zone. In the upper parts of bed 5, only a few specimens of Endocostea coxi (Reyment) and Endocostea jolkicevi Walaszczyk, Odin and Dhondt were obtained. Single specimens of Platyceramus salisburgensis (Fugger and Kastner) and fragmentary "Inocera- mus" cf. ianjonaensis were also found. This poor assemblage indicates the "II." ianjonaensis Zone, defined in the lower part of the upper Maastrichtian of South Africa (Walaszczyk et al., 2009).

Taking into account the total extent of the Cerodinium diebelii Zone (Kirsch, 1991; Roncaglia and Corradini, 1997), which is known to span the lower Maastrichtian and the lower part of the upper Maastrichtian, and also the occurrence of Alterbidinium acutulum in bed 5, the lower/ upper Maastrichtian boundary can be tentatively drawn at this level. This assumption accords with the scattered inoceramid data. The LO of A. acutulum was considered as a potential marker for the lower/upper Maastrichtian boundary (Schioler and Wilson, 2001; Radmacher et al., 2014), but our record, even though reminiscent, is not adequate to that from elsewhere.

\section{INOCERAMID BIOZONATION}

The inoceramid record of the studied sections allowed following the inoceramid assemblages in superposition and correlation with the inoceramid biozonations for the upper Campanian-Maastrichtian interval in the U.S. Western Interior (Walaszczyk et al., 2001), the Tercis section (SW France) (Walaszczyk et al., 2002) and the Vistula section (Poland) (Walaszczyk, 2004) (see Fig. 5). The youngest inoceramid fauna recorded in the Darmantsi section appears to match well with the inoceramid associations from the lower upper Maastrichtian from northeast Belgium and the Aachen area (Germany) (Walaszczyk et al., 2010), as well as with those from 


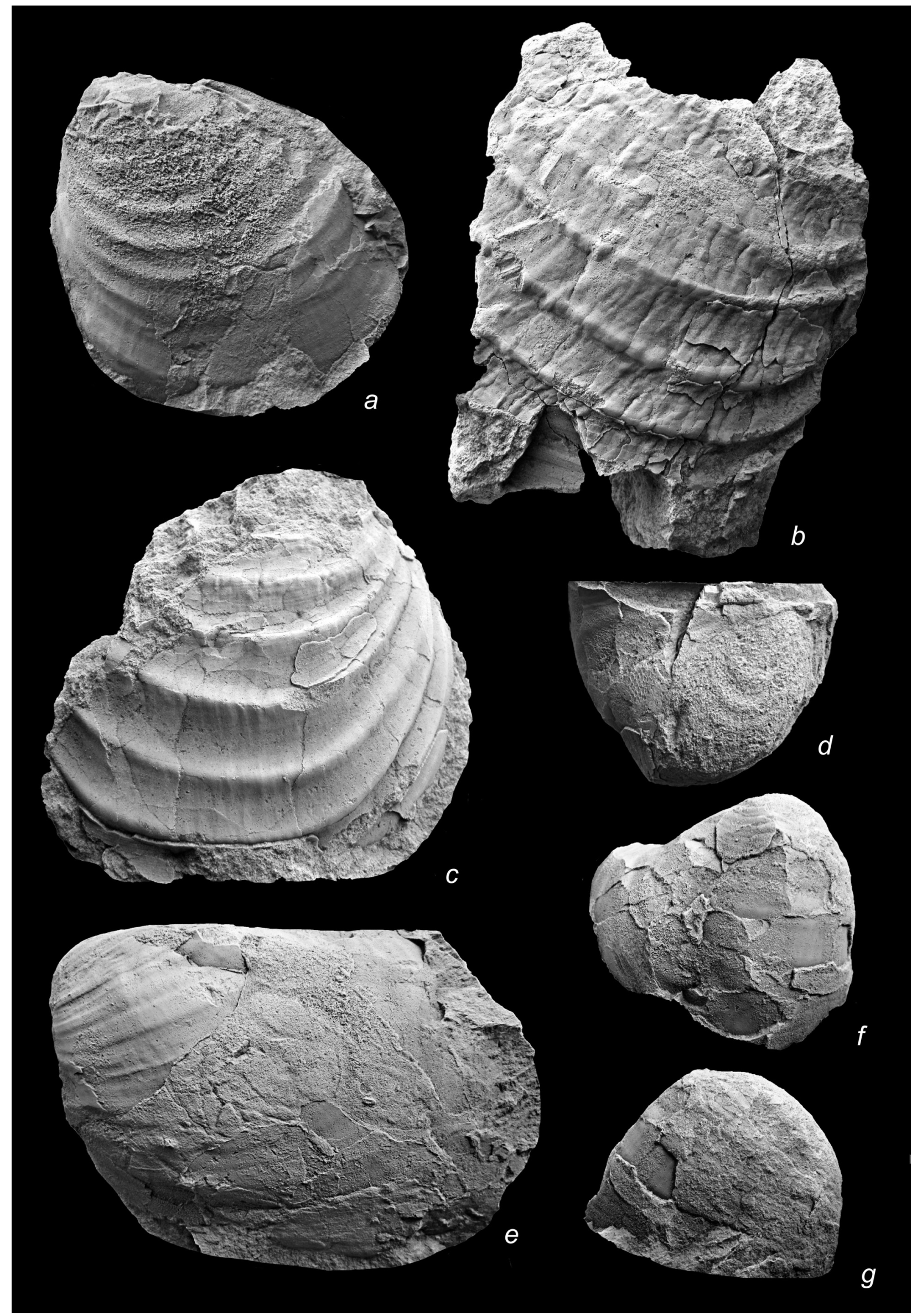


Fig. 9. Lower Maastrichtian inoceramid bivalves from the Western Fore-Balkan Mts region: $a-c$ ) Trochoceramus radiosus (Quaas); $a$ - Inv.-Nr U.S., $\mathrm{K}_{2}$ 1775, Kunino section (bed 11), T. radiosus Zone; $b$ - Inv.-Nr U.S., $\mathrm{K}_{2}$ 1776, Darmantsi section (upper part of bed 3), T. radiosus Zone; c - Inv.-Nr U.S., $\mathrm{K}_{2}$ 1777, Darmantsi section (lower part of bed 2), T. radiosus Zone; $d, f, g$ ) “Inoceramus” cf. incurvus Meek and Hayden, Inv.-Nr U.S., $\mathrm{K}_{2}$ 1770, Kunino section (upper part of bed 8), upper part of the E. typica Zone; e) Cataceramus barabini (Morton), Inv.-Nr U.S., $\mathrm{K}_{2}$ 1768, Kunino section (uppermost part of bed 7), lower part of the E. typica Zone. Figured specimens were covered with ammonium chloride before being photographed. All figures are in natural size.

Zululand and Natal, South Africa (Walaszczyk et al., 2009). The bulk of the inoceramid zones recognized herein are interval zones, with lower boundaries marked by the first occurrence of the index species, and only one zone was defined as a range zone. From bottom to top, the following zones were either recognized or indicated: "Inoceramus" redbirdensis Zone, Endocostea typica Zone, Trochoceramus radiosus Zone and "Inoceramus" ianjonaensis Zone.

\section{“Inoceramus" redbirdensis Zone}

This zone was recognized at first in the upper Campanian of the U.S. Western Interior Basin (Walaszczyk et al., 2001), and afterwards in Tercis (Walaszczyk et al., 2002a, b) and the Vistula River Valley (Walaszczyk, 2004). According to Walaszczyk et al. (2001), the limits of the zone are drawn between the first occurrence of the index-taxon and the first occurrence of Endocostea typica. The zone was indicated in the lowermost part of the Reselets section, where "Inoceramus" cf. wyomingensis was found.

\section{Endocostea typica Zone}

This zone was defined in the lower Maastrichtian of the U.S. Western Interior (Walaszczyk et al., 2001) and later confirmed in the Tercis section (Walaszczyk et al., 2002a, b). It was also recognized in the Vistula River section, but interpreted otherwise in terms of position of the Campanian/Maastrichtian boundary (see Walaszczyk, 2004). The zone is limited between the mass-incoming of the index taxon and the FO of Trochoceramus radiosus (Walaszczyk et al., 2002b). It was recognized in the Reselets and Kunino sections. In the Kunino section, the lower boundary of the zone cannot be drawn due to the lack of inoceramids. In both the Reselets and Kunino sections, small-sized specimens of the index-taxon, accompanied by Cataceramus subcircularis, C. palliseri, C. barabini and C. oviformis, occur in the lower part of the zone. In addition to these taxa, characteristic Cataceramus glendivensis occur in the upper part of the zone. Besides, in the upper part of the Kunino section, "Inoceramus" aff. tenuilineatus was also documented. Single specimens identified as "Inoceramus" cf. incurvus appear in the uppermost part of the zone as well. Based on the first occurrence of "I." incurvus, Walaszczyk et al. (2001) proposed the eponymous interval zone, located between the E. typica and Trochoceramus radiosus zones (see Fig. 5). We cannot recognize the "Inoceramus" incurvus Zone since we have scarce material.

\section{Trochoceramus radiosus Zone}

Initially, this zone was proposed for the U.S. Western Interior (Walaszczyk et al., 2001) as corresponding to the range of the index-species. Similarly, it was recognized as the highest discernible inoceramid zone in the succession at Tercis (Walaszczyk et al., 2002a, b). However, the T. radiosus Zone was defined in Zululand (South Africa) as limited between the FO of the index-taxon and the FO of "Inoceramus” ianjonaensis (Walaszczyk et al., 2009). The zone was indicated in the upper part of the Kunino section, where Trochoceramus radiosus, C. glendivensis, $C$. subcircularis and $C$. barabini occur. It was also indicated in the lower part of the Darmantsi section, where the index-species co-occurs with C. barabini, C. subcircularis, C. aff. goldfussianus and Platyceramus stephensoni. Both the lower and the upper boundary of the zone cannot be drawn due to the lack of continuous inoceramid record. 


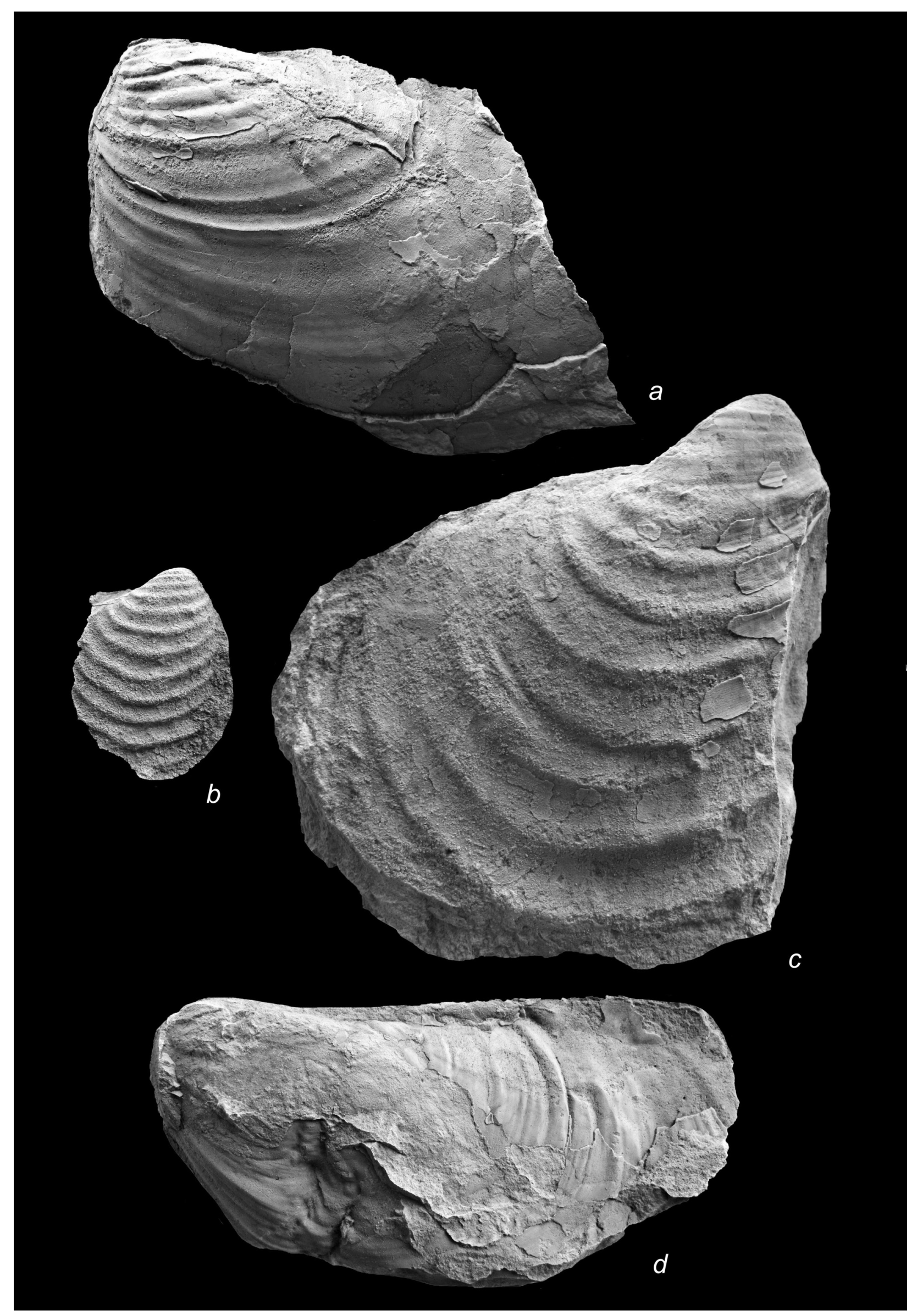


Fig. 10. Lower Maastrichtian inoceramid bivalves from the Western Fore-Balkan Mts region: a) "Inoceramus” aff. wyomingensis Walaszczyk, Cobban and Harries, Inv.-Nr U.S., K 2 1769, Kunino section (bed 7), lower part of the E. typica Zone; b) Cataceramus subcircularis Meek, Inv.-Nr U.S., $\mathrm{K}_{2}$ 1779, Darmantsi section (upper part of bed 3), T. radiosus Zone; c) “Inoceramus” howletti Walaszczyk, Kennedy and Klinger, Inv.-Nr U.S., $\mathrm{K}_{2}$ 1780, Darmantsi section (lower part of bed 4), T. radiosus Zone; d) Cataceramus barabini (Morton), Inv.-Nr U.S., $\mathrm{K}_{2} 1753$, Reselets section (uppermost part of bed 7), lower part of the E. typica Zone. Figured specimens were covered with ammonium chloride before being photographed. All figures are in natural size.

\section{“Inoceramus" ianjonaensis Zone}

This zone was defined in the upper Maastrichtian of Zululand and Natal (South Africa) by Walaszczyk et al. (2009), where it was confined to the range of the index-species. In our successions, it was indicated in the upper part of the Darmantsi section, where "Inoceramus" cf. ianjonaensis and Endocostea coxi were recognized. We should note that these finds were collected together with a typical upper Maastrichtian ammonite, Pachydiscus (Pachydiscus) gollevillensis (d’Orbigny).

\section{DINOFLAGELLATE CYST BIOSTRATIGRAPHY AND CORRELATION}

Correlation between the Maastrichtian dinocyst zones introduced by Kirsch (1991), Schioler and Wilson (1993), Roncaglia and Corradini (1997) and Roncaglia (2002) is not easy, but, regardless of some differences, it seems that these schemes have enough similarities with each other as some taxa, such as Cerodinium diebelii, Cannosphaeropsis utinensis, Isabelidinium bakeri, Isabelidinium cooksoniae, Triblastula utinensis and Microdinium carpentierae, appear to have a similar distribution pattern and thus may prove important interregional marker species. Kirsch (1991) first proposed a dinoflagellate cyst zonation for the Maastrichtian in Upper Bavaria and adjacent areas and recognized two dinocyst zones: the Cerodinium diebelii Interval Zone and the Palynodinium bicculeus Interval Zone. Schioler and Wilson (1993) analyzed diverse dinoflagellate cyst assemblages from the Dan Field (Danish North Sea). Within the stratigraphic extent from the upper lower Maastrichtian to the upper Maastrichtian, they recognized four zones and three subzones. The Triblastula utinensis Range Zone of these authors partly correlates with the C. diebelii Zone of Kirsch (1991) and is subdivided into three interval subzones: Eatonycysta hapalata; Alterbidinium acutulum; and Cannosphaeropsis utinenstis. Schioler and Wilson (1993) introduced the Isabelidinium cooksoniae Interval Zone, which is directly above the Triblastula utinensis Zone and corresponds to the lower part of the upper Maastrichtian. Roncaglia and Corradini (1997) and Roncaglia (2002) also recognized the Cerodinium diebelii Interval Zone for the lower-middle Maastrichtian in Italy. They also pointed out that the LO of Cannosphaeropsis utinensis is within the early late Maastrichtian time interval.

Schioler and Wilson (2001) proposed dinoflagellate biostratigraphy around the Campanian/Maastrichtian boundary in its GSSP at Tercis, southwest France. They defined seven key cosmopolitan dinoflagellate cyst events, considered to represent potential markers for the Campanian/Maastrichtian boundary (CMB) in this section, and compared their results with previous records from central and northern Europe. Their events are as follows: 1 ) the LO of the genus Odontochitina; 2) the FO of Cerodinium diebelii; 3) the FO of Microdinium carpentierae; 4) the LO of Xenascus ceratioides; 5) the LO of Chatangiella robusta; 6) the LO of Corradinisphaeridium horridum; and 7) the LO of Samlandia carnarvonensis. Skupien and Mohamed (2008) applied this dinocyst framework for the subdivision of the upper Campanian and the lowermost Maastrichtian in the Silesian Unit (Czech Republic). They pointed out that the FO of Cerodinium diebelii is close to the Campanian/Maastrichtian boundary, but the LO of Odontochitina could be higher, in the lowermost Maastrichtian in the Western Carpathians.

The section at Zumaia, northern Spain, represents one of the best known Upper Cretaceous successions. Radmacher et al. (2014) reported rich and diverse upper Campanian and Maastrichtian dinoflagellate assemblages and events directly calibrated to the foraminiferal and nannofossil zones as well 


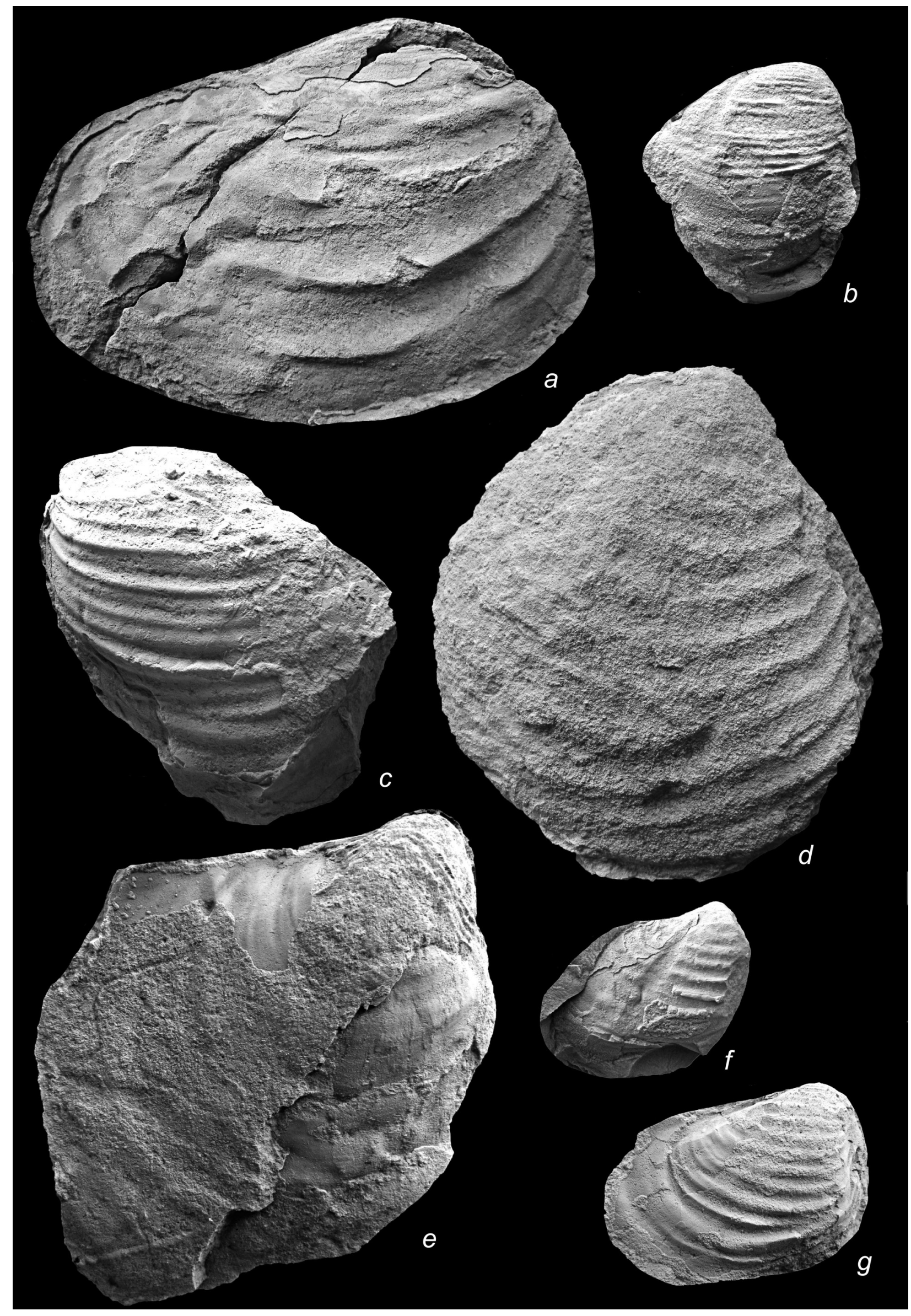


Fig. 11. Lower-upper Maastrichtian inoceramid bivalves from the Western Fore-Balkan Mts region: a) Cataceramus aff. goldfussianus (d’Orbigny), Inv.-Nr U.S., $\mathrm{K}_{2}$ 1782, Darmantsi section (base of bed 4), T. radiosus Zone; b) Endocostea jolkicevi Walaszczyk, Odin and Dhondt, Inv.-Nr U.S., $\mathrm{K}_{2}$ 1787, Darmantsi section (middle part of bed 5), lower part of the upper Maastrichtian, “Inoceramus” ianjonaensis Zone; c) “Inoceramus” cf. ianjonaensis Sornay, Inv.-Nr U.S., $\mathrm{K}_{2}$ 1785, Darmantsi section (middle part of bed 5), lower part of the upper Maastrichtian, “I.” ianjonaensis Zone; d) Platyceramus stephensoni (Walaszczyk. Cobban and Harries), Inv.-Nr U.S., K 2 1784, Darmantsi section, (uppermost part of bed 3), lower Maastrichtian, T. radiosus Zone; e) Platyceramus salisburgensis (Fugger and Kastner), Inv.-Nr U.S., $\mathrm{K}_{2}$ 1783, Darmantsi section (middle part of bed 5), lower part of the upper Maastrichtian, “I." ianjonaensis Zone; $f, g$ ) Endocostea coxi (Reyment): $f$ - Inv.-Nr U.S., $\mathrm{K}_{2}$ 1788, Darmantsi section (middle part of bed 5), lower part of the upper Maastrichtian, "I”. ianjonaensis Zone; $g$ - Inv.-Nr U.S., $\mathrm{K}_{2}$ 1786, Darmantsi section (middle part of bed 5), lower part of the upper Maastrichtian, “I.” ianjonaensis Zone. Figured specimens were covered with ammonium chloride before being photographed. All figures are in natural size.

as to the magnetic polarity data (Chron C32n.2n) in the section. The authors confirmed the value of the selected dinoflagellate bioevent stratigraphy used to identify the CMB at Tercis and emphasized once again the value of the FO of Cerodinium diebelii, together with the LO of the genus Odontochitina within the criteria. The Zumaia section has been proposed as a potential substage boundary stratotype for the lower/upper Maastrichtian (Odin et al., 1996). The definition of this boundary is still pending, but Radmacher et al. (2014) pointed out that the stratigraphical range of Alterbidinium acutulum and Hystrichodinium pulchrum is within the lower Maastrichtian and their last occurrences may be considered as potential substage boundary markers of a high correlation value.

The dinocyst succession recorded in the Western Fore-Balkan Mts sections is generally in accordance with the overall European dataset and provides inoceramid-correlated dinocyst ranges. It confirms marker events of first and last occurrences with high correlation value outside the studied area. The Cerodinium diebelii Interval Zone was indicated in two of the studied sections, Kunino and Darmantsi, with stratigraphical range from the lower Maastrichtian to the lower upper Maastrichtian and direct correlation to the E. typica, T. radiosus and "I." ianjonaensis inoceramid zones. It is a local equivalent to the $C$. diebelii Interval Zone from Upper Bavaria (Kirsch, 1991) and Italy (Roncaglia and Corradini, 1997; Roncaglia, 2002). Apart from the index species, the zonal association also includes characteristic taxa, i.e., Cannosphaeropsis utinensis, Microdinium carpentierae, Triblastula utinensis, Isabelidinium cooksoniae, I. bakeri, Tanyosphaeridium xanthiopyxides, Alterbidinium acutulum, Areolige- ra medusettiformis and Areoligera volata. In addition, the zone partially correlates with the Triblastula utinensis Range Zone (Schioler and Wilson, 1993), also having characteristic zonal association and due to the occurrence of the index species.

Four important dinocyst occurrences of high correlation value were documented in this study with regard to the $C$. diebelii Interval Zone. They confirm the value of the selected dinoflagellate bioevent stratigraphy in regards to both the Campanian/Maastrichtian boundary and the Maastrichtian stratigraphic subdivision. Firstly, it is the conspicuous acme of Cannosphaeropsis utinensis, documented within the zone in the Kunino section. It enables correlation with the Alterbidinium varium Subzone (Kirsch, 1991), as well as with the Cannosphaeropsis utinenstis Subzone (Schioler and Wilson, 1993), both of late early Maastrichtian age. The range of $C$. utinensis in the Bulgarian sections is in the lower Maastrichtian, i.e., the same as those reported from southern Germany (Kirsch, 1991), Italy (Roncaglia, 2002) and the southern hemisphere (Williams et al., 2004). Secondly, the LO of Alterbidinium acutulum also indicates an age not younger than the early Maastrichtian (Schioler and Wilson, 2001; Radmacher et al., 2014). In our study, it was recorded in the lower Maastrichtian, below the "I." ianjonaensis Zone, and was used as aid for tracing the lower/upper Maastrichtian boundary in the Darmantsi section. Thirdly, the FO of Microdinium carpentierae was found above the Campanian/Maastrichtian boundary in the Reselets section and correlated with the E. typica inoceramid Zone. The FO of this species was considered to represent a cosmopolitan key marker for the Campanian/ Maastrichtian boundary in its type section at Tercis, 

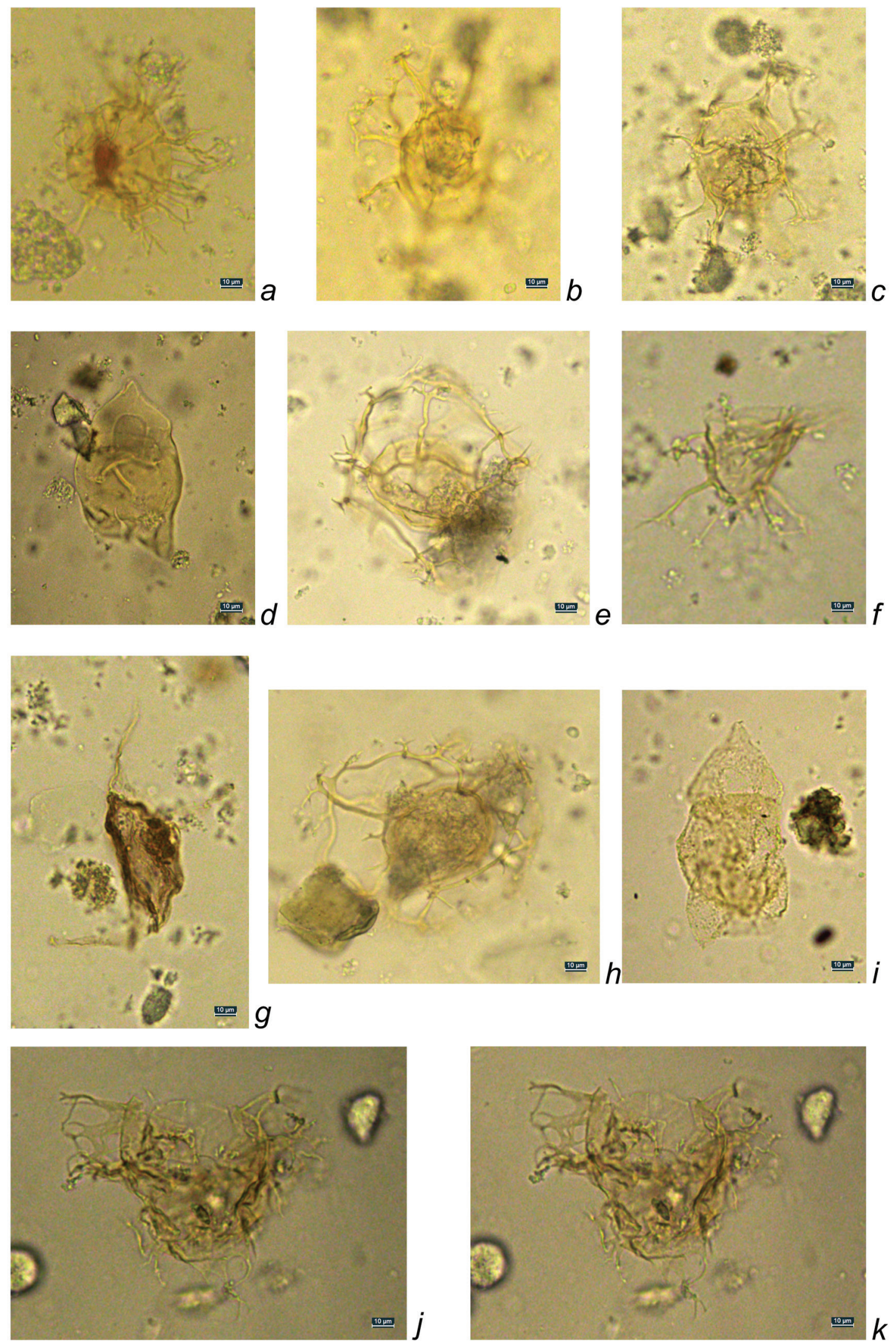

France (Schioler and Wilson, 2001). In our study, we support the value of this FO and use it for the location of the Campanian/Maastrichtian boundary in the section, correlated with the inoceramid data. Fourthly, it is the LO of Odontochitina operculata in the lowermost Maastrichtian in the Reselets section. 
Fig. 12. Microphotographs of characteristic dinocyst species from the studied sections: a) Achomosphaera ramulifera (Deflandre) Evitt, Reselets section (bed 22, sample R-5); $b, c$ ) Hystrichosphaeridium salpingophorum (Deflandre) Deflandre, Kunino section (bed 11, sample K-4); d) Isabelidinium bakeri (Deflandre and Cookson) Lentin and Williams, Darmantsi section (bed 5, sample D-4); e, h) Cannosphaeropsis utinensis Wetzel, Kunino section (bed 11, sample K-4); f) Tanyosphaeridium xanthiopyxides (Wetzel) Stover and Evitt, Kunino section (bed 11, sample K-4); g) Cerodinium diebelii (Alberti) Lentin and Williams, Kunino section (bed 11, sample K-4); i) Isabelidinium cooksoniae (Alberti) Lentin and Williams, Darmantsi section (bed 5, sample D-4); j, k) Areoligera medusettiformis (Wetzel) Lejeune-Carpentier, Kunino section (bed 11, sample K-4).

The highest occurrence of Odontochitina was accepted as a cosmopolitan key biostratigraphic event reported in the proximity of the Campanian/Maastrichtian boundary. Its LO was documented in the uppermost Campanian at Tercis and Zumaia (Schioler and Wilson, 2001; Radmacher et al., 2014), but also higher, in the lowermost Maastrichtian of Italy, the Western Carpathians and other sections of the southern hemisphere (Roncaglia, 2002; Williams et al., 2004; Skupien and Mohamed, 2008). Our data confirm that the $\mathrm{LO}$ of $O$. operculata is at the base of the Endocostea typica inoceramid Zone.

\section{PALEOENVIRONMENTAL INTERPRETATIONS}

The paleoenvironmental analysis of this study is based mainly on the encountered palynological associations. Dinoflagellate cyst assemblages are very useful to interpret the depositional environments in terms of water depth, depositional energy, temperature and nutrient availability. They possess members that are either dominantly heterotrophic (the peridinioid cysts or P-cysts) or phototrophic (the gonyaulacoid type cysts or G-cysts). Surfacewater nutrient levels and primary productivity are properly estimated by the ratio between these two groups. The $\mathrm{P} / \mathrm{G}$ ratio provides an accurate measure of surface water nutrient availability and productivity (e.g., Bujak, 1984; Pearce et al., 2009). The domination of G-cysts, or low values of the P/G ratio, is considered to be indicative of both normal nutrient supply and oligotrophic conditions. In addition, paleoenvironmentally significant dinoflagellate cyst groups have been recognized, based on the ecological information for modern analogs and known distribution patterns of some Cretaceous genera (Leereveld, 1995). Also, certain dinoflagellates are considered as temperature sensitive indicators. Their presence gives valuable climatic signals about the ocean surface water temperature (SST) during the studied time interval.

Dinoflagellate cyst assemblages in the studied sections are dominated by thin-walled chorate gonyaulacoid cysts belonging to the genera Spiniferites, Achomosphaera, Sulcolospaheridium, Tanyosphaeridium and Peridinium. Peridinioid cysts are subordinate, mainly of the genera Cerodinium and Isabelidinium. The encountered low P/G ratio values, as well as the marked domination of delicate chorate dinocysts in all sections, is considered to indicate stable low-energy depositional environment and oligotrophic conditions, with normal marine productivity and nutrient availability in the basin during the Maastrichtian. The depositional environment could be further inferred by the domination of Spiniferites representatives (including the morphologically comparable Achomosphaera). They comprise the Neritic group since, at present, this genus has its highest abundance in open-marine neritic environments (Harland, 1983). In the Cretaceous fossil record, this was confirmed by Leereveld (1995), who recognized environmentally controlled dinocyst groups and considered this genus to be typical for outer-shelf depositional environments with normal marine salinity conditions. Moreover, the occurrence of typical open-oceanic dinocysts like Peridinium confirms such conclusion. The ratio of continental to marine palynomorphs ( $\mathrm{C} / \mathrm{M}$ ratio) is very low in all samples, indicating again low terrestrial input in the basin.

The constant presence of thermophyllic dinoflagellate cysts belonging to Cerodinium is indicative of subtropical conditions (Gedl, 2004). It points to rather stable and warm surface waters in the ba- 

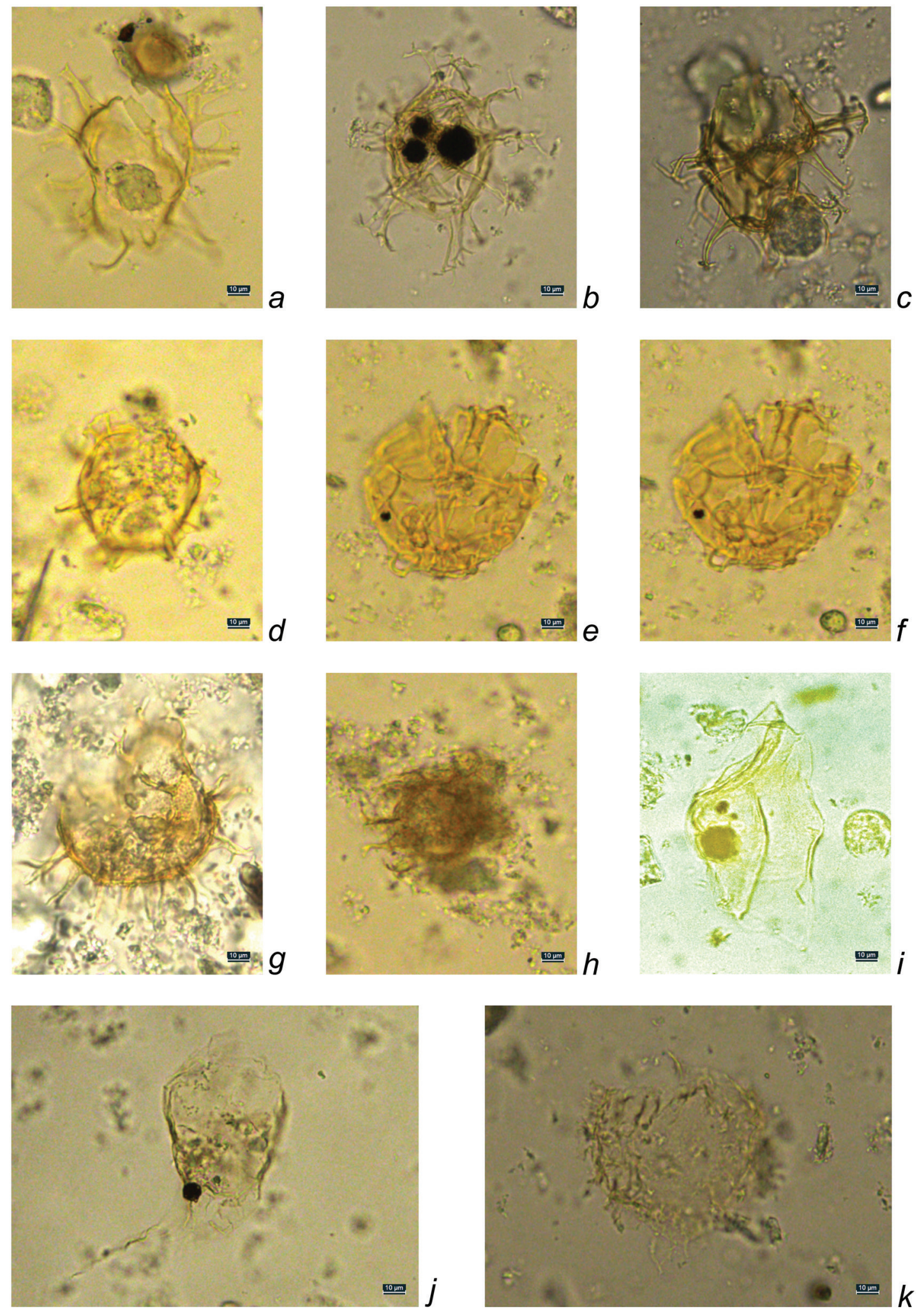

Fig. 13. Microphotographs of characteristic dinocyst species from the studied sections: a) Hystrichosphaeridium tubiferum (Ehrenberg) Deflandre, Kunino section (bed 11, sample K-4); b, c) Spiniferites ramosus ramosus (Ehrenberg) Davey and Williams, Kunino section (bed 11, sample K-4); d) Peridinium cingulatum (Wetzel) Belo, Reselets section (bed 7, sample R-4); $e$, f) Microdinium carpentierae Slimani, Reselets section (bed 4, sample R-2); g, h) Achomosphaera sagena Davey and Williams, Reselets section (bed 2, sample R-1); i) Alterbidinium acutulum (Wilson) Lentin and Williams, Darmantsi section (bed 5, sample D-4); j) Odontochitina operculata (Wetzel) Deflandre and Cookson, Reselets section (bed 5, sample R-3); ) Areoligera volata Drugg, Kunino section (bed 11, sample K-4). 
sin, consistent with the warm or subtropical climate that prevailed during the late Campanian and the early Maastrichtian.

\section{CONCLUSIONS}

Inoceramid bivalves and dinoflagellate cysts of the topmost Campanian-Maastrichtian were documented in the Reselets, Kunino and Darmantsi sections of the Western Fore-Balkan Mountains (Bulgaria). Four inoceramid zones were identified: the "Inoceramus" redbirdensis Zone, the Endocostea typica Zone, the Trochoceramus radiosus Zone and the "Inoceramus" ianjonaensis Zone. The Campanian/Maastrichtian boundary was tentatively drawn slightly below the FO of Endocostea typica. The youngest inoceramid assemblage was recorded in the upper part of the Darmantsi section and indicated the presence of the "Inoceramus" ianjonaensis Zone in the lower part of the upper Maastrichtian.

A succession of key dinoflagellate cyst events was recorded and directly correlated with the inoceramid record. The dinocyst assemblages were also compared with coeval events and zones in Europe, and the Cerodinium diebelii Zone was indicated, having a stratigraphical range from the lower Maastrichtian to the lower upper Maastrichtian. Two important dinocyst occurrences were documented around the Campanian/Maastrichtian boundary in the Reselets section: 1) the FO of Microdinium carpentierae; and 2) the LO of Odontochitina, in the lowermost Maastrichtian. The LO of Alterbidinium acutulum was recorded in the lower Maastrichtian and used as aid for tracing the lower/upper Maastrichtian boundary in the Darmantsi section.

The paleoenvironmental analysis, based on the dinoflagellate cyst assemblages, revealed that they are dominated by thin-walled chorate gonyaulacoid cysts and subordinate peridinioid cysts. The encountered low P/G ratio values and the marked domination of delicate chorate dinocysts in all sections were considered to indicate stable low-energy depositional environment and oligotrophic conditions, with normal marine productivity and nutrient availability. The assemblages are also characterized by the domination of Spiniferites and Achomosphaera representatives, considered to be typical for outer-shelf depositional environments with normal marine salinity. The presence of thermophyllic dinoflagellate cysts belonging to Cerodinium points to a rather stable and warm surface waters in the basin and subtropical climate during the early Maastrichtian.

\section{Acknowledgements}

This study is a contribution to the project "Late Cretaceous palaeoclimate events and stage boundaries correlations - evidence from Tethyan key sections of Bulgaria and Austria” and part of the Bilateral Bulgarian - Austrian collaboration financed by the Bulgarian Scientific Fund and OeAD GmbH, Austria (Project KP-06-Austria/9). We are grateful to official journal reviewers Prof. Ireneusz Walaszczyk (University of Warsaw, Poland) and Dr James Riding (British Geological Survey, UK) for muchappreciated constructive criticism.

\section{REFERENCES}

Bujak, J.P. 1984. Cenozoic dinoflagellate cysts and acritarchs from the Bering Sea and northern North Pacific. D.S.D.P. leg 19. Marine Micropalaeontology 30, 180-212.

Crampton, J.S. 1996. Inoceramid bivalves from the late Cretaceous of New Zealand. Monographs of the Institute of Geological and Nuclear Sciences 14, 1-188.

Dabovski, H., Kamenov, B., Sinnyovsky, D., Vasilev, E., Dimitrova, E., Bayraktarov, I. 2009. Chapter 5.5. Upper Cretaceous geology. In: Zagorchev, I., Dabovski, Ch., Nikolov, T. (Eds), Geology of Bulgaria. Vol. II. Mesozoic geology. "Prof. Marin Drinov" Academic Press, Sofia, 303-589 (in Bulgarian, with English summary).

Dhondt, A.V. 1993. Upper Cretaceous bivalves form Tercis, Landes, SW France. Bulletin de l'Institut Royal des Sciences Naturelles de Belgique 63, 211-259.
Dochev, D., Metodiev, L. 2015. New inoceramid bivalves of the genera Endocostea Whitfield, 1877 and Trochoceramus Heinz, 1932 from the Western Fore-Balkan (Bulgaria). Bulgarian Geological Society, National Conference with International Participation “Geosciences 2015”, Abstracts, 107-108.

Dochev, D., Metodiev, L. 2020. Inoceramid bivalves from the Maastrichtian of the Western Fore-Balkan Mts (Bulgaria). Geologica Balcanica 49 (1), 31-52.

Dochev, D., Pavlishina, P., Petkanska, P., Vladimirova, E. 2018. Preliminary results about the Campanian/Maastrichtian boundary in Reselets section (Western Fore-Balkan), based on inoceramid bivalves, ammonites and dinoflagellate cysts. Review of the Bulgarian Geological Society 79 (3), 87-88. 
Douglas, R.J. 1942. New species of Inoceramus from the Cretaceous Bearpaw Formation. Transactions of the Royal Society of Canada 4, 59-65.

Gale, A.S., Hancock, J.M., Kennedy, W.J., Petrizzo, M.R., Lees, J.A., Walaszczyk, I., Wray, D.S. 2008. An integrated study (geochemistry, stable oxygen and carbon isotopes, nannofossils, planktonic foraminifera, inoceramid bivalves, ammonites and crinoids) of the Waxahachie Dam Spillway section, north Texas; a possible boundary stratotype for the base of the Campanian Stage. Cretaceous Research 29 (1), 131-167.

Gedl, P. 2004. Dinoflagellate cyst record of the deep-sea Cretaceous-Tertiary boundary at Uzgrun, Carpathian Mountains, Czech Republic. In: Odin, G.S. (Ed), The CampanianMaastrichtian boundary. Elsevier, Amsterdam, 257-273.

Harland, R. 1983. Distribution maps of recent dinoflagellate cysts in bottom sediments from the North Atlantic Ocean and adjacent seas. Palaeontology 26, 321-387.

Harries, P.J., Crampton, J.S. 1998. The Inoceramids. American Palaeontologist 6 (4), 2-6.

Ivanov, Ž. 1998. Tectonics of Bulgaria. Professorship thesis, Sofia University “St Kliment Ohridski”, 579 pp. (in Bulgarian, unpublished).

Ivanov, Ž. 2017. Tectonics of Bulgaria. Sofia University Press, Sofia, 331 pp. (in Bulgarian, with English summary).

Jolkičev, N.A. 1982. Stratigraphie der Coniac-MaastrichtAblagerungen in den Zentralteilen des Vorbalkans und der Mösischen Platte. Annual of the Sofia University "St Kliment Ohridski”, Faculty of Geology and Geography 72 (1), 5-78 (in Bulgarian, with German abstract).

Jolkičev, N.A. 1986. Lithostratigraphic units related to the Upper Cretaceous in the West and Central Fore-Balkan. Review of the Bulgarian Geological Society 47 (3), 49-61 (in Bulgarian, with English abstract).

Jolkičev, N. A. 1989. Stratigraphy of the epicontinental type Upper Cretaceous in Bulgaria. Kliment Ohridski University Press, Sofia, 184 pp. (in Bulgarian, with English abstract).

Kauffman, E.G., Sageman, B.B., Kirkland, J.I., Elder, W.P., Harries, P.J., Villamil, T. 1993. Molluscan biostratigraphy of the Cretaceous Western Interior Basin, North America. Geological Association of Canada, Special Paper 39, 397433.

Kirsch, K. 1991. Dinoflagellatenzysten aus der Oberkreide des Helvetikums und Nordultrahelvetikums von Oberbayern. Münchner Geowissenschaftliche Abhandlungen, Reihe A, Geologie und Paläontologie 22, 1-306.

Leereveld, H. 1995. Dinoflagellate cysts from the Lower Cretaceous Rio Argos succession (SE Spain). LPP Contribution Series 2, LPP Foundation, Utrecht, 175 pp.

Meek, F.B. 1876. A report of the invertebrate Cretaceous and Tertiary fossils of the upper Missouri country. Geological Survey of the Territories (Hayden) Report 9, 629 pp.

Meek, F.B, Hayden, F.V. 1856. Descriptions of new species of Gastropoda and Cephalopoda from the Cretaceous formations of Nebraska Territory. Proceedings of the Philadelphia Academy of Natural Sciences 8, 63-126.

Morton, S.G. 1834. Synopsis of the organic remains of the Cretaceous group in the United States. Key and Biddle, Philadelphia, 88 pp.

Odin, G.S. 2001. The Campanian-Maastrichtian boundary: correlation from Tercis (Landes, SW France) to Europe and other continents. In: Odin, G.S. (Ed.), The CampanianMaastrichtian Stage Boundary: Characterization at Tercis les Bains (France) and correlation with Europe and other continents. Elsevier Science, Amsterdam, 805-819.

Odin, G.S., Hancock, J.M, Antonescu, E., Bonnemaison, M., Caron, M., Cobban, W.A., Dhondt, A.V., Gaspard, D., Ion,
J., Jagt, J.W.M., Kennedy, W.J., Melinte, M., Néraudeau, D., von Salis, K., Ward, P.D. 1996. Definition of a global boundary stratotype section and point for the Campanian/ Maastrichtian boundary. Bulletin de l'Institut Royal des Sciences Naturelles de Belqique, Sciences de la Terre 66 (Supplementary), 111-117.

Pearce, M.A., Jarvis, J., Toucher, B.A. 2009. The CenomanianTuronian boundary event and palaeoenvironmental change in epicontinental seas: new insights from the dinocyst and geochemical records. Palaeogeography, Palaeoclimatology, Palaeoecology 280, 207-234.

Radmacher, W., Perez-Rodríguez, I., Arz, J., Pearce, M. 2014. Dinoflagellate biostratigraphy at the Campanian-Maastrichtian boundary in Zumaia, northern Spain. Cretaceous Research 51, 309-320.

Reyment, R.A. 1955. Upper Cretaceous Mollusca (Lamellibranchia and Gastropoda) from Nigeria. Geological Survey Department Nigeria. Colonial Geology and Mineral Resources 5, 127-155.

Redtenbacher, A. 1873. Die Cephalopoden der Gosauschichten in den nordöstlichen Alpen. Abhandlungen der Kaiserlich-Königlich Geologischen Reichsanstalt 5, 91-140.

Roncaglia, L. 2002. Lower Maastrichtian dinoflagellates from the Viano Clay Formation at Viano, northern Apennines, Italy. Cretaceous Research 23, 65-76.

Roncaglia, L., Corradini, D. 1997. Correlation of key dinoflagellate events with calcareous nannoplankton and planktonic foraminiferal zones in the Solignano Formation (Maastrichtian, Late Cretaceous), northern Apennines, Italy. Review of Palaeobotany and Palynology 97, 177-196.

Schioler, P., Wilson, G.J. 1993. Maastrichtian dinoflagellate zonation in the Dan Field, Danish North Sea. Review of Palaeobotany and Palynology 78, 321-351.

Schioler, P., Wilson, G.J. 2001. Dinoflagellate biostratigraphy around the Campanian-Maastrichtian boundary at Tercis les Bains, southwest France. In: Odin, G.S. (Ed.), The Campanian-Maastrichtian Stage Boundary: Characterization at Tercis les Bains (France) and correlation with Europe and other continents. Elsevier Science, Amsterdam, 221-234.

Skupien, P., Mohamed, O., 2008. Campanian to Maastrichtian palynofacies and dinoflagellate cysts of the Silesian Unit, Outer Western Carpathians, Czech Republic. Bulletin of Geosciences 83 (2), 207-224.

Sornay, J. 1973. Sur les inocérames du Maastrichtien de Madagascar et sur une espèce de la Craie à Baculites du NW de la France. Annales de Paléontologie (Invertébrés) 59, 83-93.

Tzankov, Tz., Nedjalkova, L., Aladžova-Khrischeva K., Khrischev, Kh, Angelova, D. 1994. Geological map of the Republic of Bulgaria 1:100 000, Cherven bryag map sheet. Committee on Geology, Company for Geophysical Surveys and Geological Mapping, Sofia.

Tzankov, Tz., Nedjalkova, L., Angelov, V., Aladžova-Khrischeva, K., Yanev, S., Haydoutov, I., Sapunov, I., Tchoumatchenko, P. 1995. Geological map of the Republic of Bulgaria 1:100 000, Vraca map sheet. Committee on Geology, Company for Geophysical Surveys and Geological Mapping, Sofia.

Tzankov, V. 1981. Les fossiles de Bulgarie. V. Crétacé supérieur. Grandes foraminifères, Anthozoaires, Gastéropodes, Bivalvia. Académie bulgare des Sciences, Sofia, 233 pp. (in Bulgarian, with French abstract).

Walaszczyk, I. 2004. Inoceramids and inoceramid biostratigraphy of the Upper Campanian to basal Mastrichtian of the Middle Vistula River section, central Poland. Acta Geologica Polonica 54 (1), 95-168. 
Walaszczyk, I., Cobban, W.A., Harries, P.J. 2001. Inoceramids and inoceramid biostratigraphy of the Campanian and Maastrichtian of the United States Western Interior Basin. Revue de paléobiologie 20 (1), 117-234.

Walaszczyk, I., Odin, G.S., Dhondt, A.V. 2002a. Inoceramids from the Upper Campanian and Lower Maastrichtian of the Tercis section (SW France), the Global Stratotype Section and Point for the Campanian-Maastrichtian boundary; taxonomy, biostratigraphy and correlation potential. Acta Geologica Polonica 52 (3), 269-305.

Walaszczyk, I., Cobban W.A., Odin, G.S. 2002b. The inoceramid succession across the Campanian-Maastrichtian boundary. Bulletin of the Geological Society of Denmark 49, 53-60.

Walaszczyk, I., Jagt, J.W.M., Keutgen, N. 2010. The youngest Maastrichtian 'true' inoceramids from the Vijlen Member (Gulpen Formation) in northeast Belgium and the Aachen area (Germany). Netherlands Journal of Geosciences 89 (2), 147-167.
Walaszczyk, I., Kennedy, W.J., Klinger, H.C. 2009. Cretaceous faunas from Zululand and Natal, South Africa. Systematic palaeontology and stratigraphical potential of the Upper Campanian-Maastrichtian Inoceramidae (Bivalvia). African Natural History 5, 49-132.

Wetzel, O., 1933. Die in organischer Substanz erhaltenen Mikrofossilien des baltischen Kreide-Feuersteins mit einem sedimentpetrographischen und stratigraphischen Anhang. Palaeontographica A, 78, $110 \mathrm{pp}$.

Whitfield, R.P. 1880. Paleontology of the Black Hills of Dakota. In: Newton, H., Jenney W.P (Eds), Report of the geology and resources of the Black Hills of Dakota. United States Geographical and Geological Survey of the Rocky Mountain Region, 325-468.

Williams, G., Brinkhuis, H., Pearce, M., Fensome, R., Weegink, W. 2004. Southern ocean and global dinoflagellate cyst events compared: Index events for the Late CretaceousNeogene. Proceedings of the Ocean Drilling Program, Scientific Results 189, 1-98. 